\title{
Investigation of Strength, Flexibility and Balance Parameters with Performance Dimension in Basketball Players
}

\author{
Ömer Özer ${ }^{1}$ \\ ${ }^{1}$ Physical Education and Sport, Karamanoğlu Mehmetbey University, Karaman, Turkey \\ Correspondence: Ömer Özer, Physical Education and Sport, Karamanoğlu Mehmetbey University, Karaman, \\ Turkey. E-mail: besyo4307@gmail.com
}

Received: August 10, 2019

Accepted: September 8, 2019

Online Published: September 20, 2019

doi:10.5539/jel.v8n5p225

URL: https://doi.org/10.5539/jel.v8n5p225

\begin{abstract}
The aim of this study is to investigate the relationship between strength, flexibility and balance parameters of male basketball players with performance dimension. Sixteen elite basketball players participated in the study voluntarily. Leg and back strength, flexibility and static and dynamic balance parameters of the participants were examined. Pearson Product Moment Correlation Coefficient method was used to determine the relationship between performance values obtained from strength, flexibility and balance parameters. As a result of the analysis of the data obtained; between LS and BS $(r=0.676 \mathrm{p}<0.01)$, SBRL and SBB $(r=0.787 \mathrm{p}<0.01)$, SBLL and SBB and SBRL $(r=0.688 p<0.01, r=0.791 p<0.01)$, DBB and SBB and SBRL $(r=0.775 p<0.01$, $r=0.752 p<0.01)$, DBRL and SBB, SBRL, SBLL and DBB $(r=0.800 p<0.01, r=0.694 p<0.01, r=0.707 p$ $<0.01, r=0.874 p<0.01)$, DBLL and SBB and SBRL $(r=0.765 p<0.01, r=0.652 p<0.01)$ are high related. Whiler there was a moderate relationship between DBB and SBLL $(r=0.610 p<0.05)$, DBRL and SBRL, DBB and DBRL $(r=0.588 p<0.05, r=0.589 p<0.05, r=0.566 p<0.05)$, there were no relationship between FLX and LS and BS(r $=0.430 \mathrm{p}>0.05, \mathrm{r}=0.155 \mathrm{p}>0.05)$, SDI SBB and LS, BS and FLX $(\mathrm{r}=0.341 \mathrm{p}>0.05, \mathrm{r}=$ $0.388 p>0.05, r=0.274 p>$ Z0.05), SDSA SBRL and LS, BS and FLX $(r=0.103 p>0.05, r=0.347 p>0.05, r$ $=0.167 p>0.05)$, SBLL and LS, BS ve FLX $(r=-0.027 p>0.05, r=0.237 p>0.05, r=0.022 p>0.05)$, DBB and LS, BS ve FLX $(r=0.211 p>0.05, r=0.306 p>0.05, r=0.268 p>0.05)$, DBRL and LS, BS and FLX $(r=$ $0.268 p>0.05, r=0.433 p>0.05, r=0.281 p>0.05)$, DBLL and LS, BS and FLX $(r=0.136 p>0.05, r=0.137$ $\mathrm{p}>0.05, \mathrm{r}=0.164 \mathrm{p}>0.05$ ). As a result, it is thought that the basketball players' performance will be increased by paying attention to the content of training programs due to the sudden direction change actions of basketball, which are related to strength, flexibility and balance parameters of male basketball players.
\end{abstract}

Keywords: basketball, balance, flexibility, strength

\section{Introduction}

In sport, "how to achieve success, how to reach the top, how to stay at the top" these questions and concerns are important in the selection of players specific to the branch and determine the training models to be applied. Therefore, researchers' interest in the performance of targets and their ability to demonstrate physical competence with scientific data is increasing each day (Albay et al., 2008). Achieving a high level of performance in sports results from a combination of many factors (Pepe \& Bozkurt 2018). The most important of these is physical fitness and training needed to be have great perfomance (Bozkurt et al., 2011; Bozkurt et al., 2011). Physical fitness is the most important criterion in determining the physiological capacity (Çakmakçi et al., 2018; Tatlici \& Cakmakci, 2019). In most sport branches, Skill-related components include speed, agility, strength, balance, coordination, and response time (Çakmakçı et al., 2019). In sport, this is well known that small times make teams or players winner (Tatlıcı ve ark 2018). In addition to these physiological features, the athlete has to perfect these features through exercises (Tatlic1 et al., 2018). Basketball is a team sport that requires high level technical skills and tactical ability (Y1lmaz et al., 2012), in which compound motoric features such as necessity of application in sudden and changing positions, coordination, reactionary properties (Akçayaka, 2009), quick strength and endurance in strength are important (Menevşe, 2013). Therefore, athletes with excellent technique and tactics can achieve success if they develop their basic motoric features systematically (Ünlü \& Tatlıc1, 2018; Polat \& Çetin, 2018). It is hard to say that success in basketball is difficult to attribute to a single criterion (Gocentas et al., 2004). In the competition characteristics of basketball, physical structure, 
physiological capacity (Kılınç, 2008; Drinkwater et al., 2008), and being tall in the physical structure are considered as an advantage (Carter et al., 2005). In addition, muscle mass and physical functions of players should be improved and individualized (Magill, 1989; Pamuk et al., 2008). Physical structure, technical, tactical and mental abilities are prominent in branches with doing ball and it is important for technical performance as well as a technical tactic for optimal performance (Tsunawake et al., 2003; Kılınç et al., 2011). In the literature, anthropometric and physiological profiles of elite basketball players were evaluated in many respects and in the evaluation results of elite basketball players, it was observed that motoric features such as experience, body composition, strength, flexibility, and balance were prioritized among other factors (Hoffmn et al., 2003; Scheller et al., 2003; Raks, 1993; Pamuk et al., 2008). When the literature is examined, it is noteworthy that anthropometric measurements, body compositions and physiological parameters of elite basketball players are noteworthy (Pazarözyurt \& Gonca, 2009; Jelicic et al., 2005; Sallet et al., 2005; Carter et al., 2005; Bale, 1990; Hoare, 2000) however there are few studies that are associated with each other. Based on this, it is aimed to examine the strength, flexibility and balance parameters of basketball players with performance dimension.

\section{Method}

\subsection{Design and Participant (Subject) Characteristics}

16 elite male basketball players from Bartın University basketball team participated in the study voluntarily. The age, height and bodyweight of the athletes are given in

Table 1 . The age, height and bodyweight of the athletes

\begin{tabular}{ll}
\hline Mean Age & $21.50 \pm 2.00$ \\
Mean Height & $187.50 \pm 8.72$ \\
Mean Weight & $82.04 \pm 12.27$ \\
\hline
\end{tabular}

\subsection{Measures and Covariates}

\section{Back Strenght Measurement}

The measurement was made with Takei (Japanese) brand digital back-leg dynamometer. While subjects placed their feet on the dynamometer stand with their knees bent, with the arms stretched, the back straight and the body slightly bent forward, the grasped dynamometer bar with hands was vertically pull up with maximum using the back muscles (Aslan et al., 2011).

\section{Sit and Reach test}

Flexibility measurements of the subjects were performed by a sit-reach test using the flexibility table. Subjects were asked to perform two trials and their best grades were recorded in $\mathrm{cm}$ (Mackenzie, 2005).

\section{Balance Performance Test}

Biodex Balance System (Biodex, Inc., Shirley, New York) was used for balance measurement. Biodex balance device; as well as a platform that allows the participant to move forward and backward and sideways as well as to remain stationary. Static balance and dynamic balance test were used. Balance tests were carried out in double feet and standing straight position. Double foot balance tests were performed 3 times with a duration of 30 seconds and a rest interval of 10 seconds. Before the tests, a 10-second retry was performed for the athletes to adapt and recognize the static and dynamic balance tests. Participants were asked not to move or speak during the test period. The test of the participants who lost their balance was restarted (Adam et al. 2008).

\subsection{Statistics Analysis}

Pearson Product Moment Correlation Coefficient method was analyzed in spss 23 program in order to determine the relationship between the obtained data and the values of force, flexibility and balance parameters.

\section{Results}

Table 2. Strenght, Flexibility and Balance correlation values of the basketball players

\begin{tabular}{|c|c|c|c|c|c|c|c|c|c|c|}
\hline Variables & & LS & BS & FLX & SBB & SBRL & SBLL & DBB & DBRL & DBLL \\
\hline LS & $\mathbf{r}$ & 1 & & & & & & & & \\
\hline BS & $\mathbf{r}$ & $.676^{* *}$ & 1 & & & & & & & \\
\hline FLX & $\mathbf{r}$ & .430 & .155 & 1 & & & & & & \\
\hline
\end{tabular}




\begin{tabular}{|c|c|c|c|c|c|c|c|c|c|c|}
\hline$\overline{\text { SBB }}$ & $\mathbf{r}$ & .341 & .388 & .274 & 1 & & & & & \\
\hline SBRL & $\mathbf{r}$ & .103 & .347 & .167 & $.787^{* *}$ & 1 & & & & \\
\hline SBLL & $\mathbf{r}$ & -.027 & .237 & .022 & $.688^{* *}$ & $.791^{* *}$ & 1 & & & \\
\hline DBB & $\mathbf{r}$ & .211 & .306 & .268 & $.775^{* *}$ & $.752^{* * *}$ & $.610^{*}$ & 1 & & \\
\hline DBRL & $\mathbf{r}$ & .268 & .433 & .281 & $.800^{* * *}$ & $.694^{* *}$ & $.707^{* *}$ & $.874^{* *}$ & 1 & \\
\hline DBLL & $\mathbf{r}$ & .136 & .137 & .164 & $.765^{* *}$ & $.588^{*}$ & $.652^{* *}$ & $.589^{*}$ & $.566^{*}$ & 1 \\
\hline
\end{tabular}

Note. *. $\mathrm{p}<0.05$ level (2-tailed). ${ }^{* *}$. $\mathrm{p}<0.01$ level (2-tailed). LS: Leg Strenght, BS: Back Strenght, FLX: Flexibility, SBB: Static Balance Two Legs, SBRL: Static Balance Right Leg, SBLL: Static Balance Left Leg, DBB: Dynamic Balance Two Legs, DBRL: Dynamic Balance Right Leg, DBLL: Dynamic Balance Right Leg.

There were correlation beetwen physical parametres of the basketball players. As it in seen in the table: LS and BS $(r=0.676 \mathrm{p}<0.01)$, SBRL and SBB $(r=0.787 \mathrm{p}<0.01)$, SBLL and SBB and SBRL $(r=0.688 \mathrm{p}<0.01, \mathrm{r}=$ $0.791 \mathrm{p}<0.01)$, DBB and SBB and SBRL $(r=0.775 \mathrm{p}<0.01 . \mathrm{r}=0.752 \mathrm{p}<0.01)$, DBRL and SBB, SBRL, SBLL and DBB $(r=0.800 \mathrm{p}<0.01, \mathrm{r}=0.694 \mathrm{p}<0.01, \mathrm{r}=0.707 \mathrm{p}<0.01, \mathrm{r}=0.874 \mathrm{p}<0.01)$, DBLL and SBB and SBRL $(r=0.765 \mathrm{p}<0.01, \mathrm{r}=0.652 \mathrm{p}<0.01)$ are high related.

While there was a moderate relationship between DBB and SBLL $(r=0.610 \mathrm{p}<0.05)$, DBRL and SBRL, DBB and DBRL $(r=0.588 p<0.05, r=0.589 p<0.05, r=0.566 p<0.05)$, there were no relationship between FLX and LS and BS(r $=0.430 \mathrm{p}>0.05, \mathrm{r}=0.155 \mathrm{p}>0.05)$, SDI SBB and LS, BS and FLX $(\mathrm{r}=0.341 \mathrm{p}>0.05, \mathrm{r}=$ $0.388 p>0.05, r=0.274 p>$ Z0.05), SDSA SBRL and LS, BS and FLX $(r=0.103 p>0.05, r=0.347 p>0.05, r$ $=0.167 p>0.05)$, SBLL and LS, BS ve FLX $(r=-0.027 p>0.05, r=0.237 p>0.05, r=0.022 p>0.05)$, DBB and LS, BS ve FLX $(r=0.211 p>0.05, r=0.306 p>0.05, r=0.268 p>0.05)$, DBRL and LS, BS and FLX $(r=$ $0.268 p>0.05, r=0.433 p>0.05, r=0.281 p>0.05)$, DBLL and LS, BS and FLX $(r=0.136 p>0.05, r=0.137$ $p>0.05, r=0.164 p>0.05$ ). It seen performance of basketball players related to strength, flexibility and balance parameters.

\section{Discussion}

Nowadays, it is seen that especially the successes and championships achieved in recent international sports activities are not easily achieved. Therefore, the necessary criteria should be determined on the way to success (Yıldırım \& Özdemir, 2010). One of the most important of these criteria is choosing the athlete who has a suitable physical and conditional structure for the related sports branch (Zorba, 1999). In many activities in basketball, the strength in many basketball activities is applied at angular velocities higher than the maximal velocities provided by isokinetic and isometric measuring tools. When the analysis of the basketball competition is analyzed, it is seen that a very important part of the movements is related to the strength and components of the whole. It is also known that the rate of fat in the body has a significant effect on the factors affecting strength. A good fat proportion of a person affects a person's strength (Akyüz et al., 2013). Soslu et al. (2016), as a result of their study with 16 male basketball players' right-left leg fat, fat mass, muscle, lean mass values, lower peak power, relative peak power, lower average power, relative average power, leg strength, determination of right-left arm fat, fat mass, muscle, lean mass values of the upper peak power, relative upper peak power, upper average power, upper relative average power, hand-arm and body strength are important factors in determining. Taş et al. (2013) found a statistically significant relationship between back and leg strength and thigh and calf circumference in their study with elite basketball players. In Akyüz et al. (2013) study with basketball national team athletes, showed that there was a statistically significant relationship between right grip force and left grip force values and back force and leg force values. Ulusu et al. (2018) in their study, 20 meters speed and horizontal jump performances of basketball players with arm, foot, stroke length, leg length, knee height, foot width, arm, thigh, calf circumference have found a positive relationship. Gencer et al. (2019) examined the relationship between basketball players' dominant and non-dominant grip strength and free throw hit rates. They also found that there was a significant relationship between the basketball player's shooting hand grasping strength and the free throw hit rate, but there was no statistically significant relationship between the shooting hand and the shooting rate. Gür et al. (2017) reported that there was a statistically positive relationship between upper extremity ekstantör strength and grip strength, vertical jump, reaction time, hand reaction time and free throw success of basketball players. Pizzigalli et al. (2016) examined the relationship between basketball players' anthropometric properties and force parameters and performance dimension and stated that there was a statistically significant relationship between hand grip strength and arm length. Temur (2017) stated that right and left hands grip strength of basketball players were significant in terms of height, body weight and arm circumference values, whereas horizontal and vertical jump distances were not statistically significant compared to thigh and calf circumference measurements. Pamuk et al. (2008) found that there was a statistically positive difference in favor of 2 nd league basketball players in terms of left-hand grip and anaerobic variables. Tetik et al. 
(2013) found that there was a positive relationship between game performance scores and static balance scores of basketball players. Yörükoğlu and Koz (2007) in their study did not find a significant difference in flexibility parameters of basketball players. Abdullah and Gencer (2013) found a significant relationship between the basketball players' dynamic balance scores and vertical jump scores. Korkmaz (2013) compared the physiological parameters of 2nd league and regional league basketball teams and showed that body fluid and fat percentage and lactic acid levels after competition were statistically significant compared to regional league basketball players of 2nd league basketball players. These studies were not only related to basketball but also tried to relate the performance with motoric features for many individual and team athletes (Albay et al., 2008; Özer \& Kılınç, 2011; Çakmakcı et al., 2018). While the present studies related to basketball players show parallelism with some studies in the literatüre, do not show parallelism with the other studies. As a result, it is thought that basketball players' strength, balance and flexibility characteristics will be determined and their performance will be improved positively through planning and programming of the training.

\section{Conclusion}

As a result, it is thought that the coaches of the basketball teams should apply training which contains flexibility, strength, balance to basketball players. Based on the study, performance can be improved by increasing strength, flexibility and balance parameters of male basketball players.

\section{References}

Abdullah, R. R., \& Gencer, Y. G. (2019). Basketbolda Dinamik Dengenin Şut İsabetine Etkisinin İncelenmesi. OPUS Uluslararast Toplum Araştırmalart Dergisi, 10(17), 1476-1494. https://doi.org/10.26466/opus.534271

Adam, M., Leblebici, B., Erkan, A. N., Bagis, S., \& Akman, M. N. (2008). Ankylosing spondylitis and postural balance/Ankilozan spondilit ve postural denge. Rheumatism, 87-91.

Akçakaya, İ. (2009). Trakya üniversitesi futbol, atletizm ve basketbol takımlarındaki sporcuların bazı motorik ve antropometrik özelliklerinin karşslaştırılması. Yüksek lisans tezi, Trakya Üniversitesi Sağlık Bilimleri Enstitüsü, EDIRNE.

Akyüz, M., Özkan, A., Taş, M., Sevim, O., Akyüz, Ö., \& Uslu, S. (2013). Yıldız Basketbol Milli Takımında Yer Alan Kız Sporcuların Kuvvet Profillerinin Belirlenmesi ve İlişkilendirilmesi. International Journal of Sport Culture and Science, 1(3), 39-48.

Albay, M. D., Tutkun, E., Ağaoğlu, Y. S., Canikli, A., \& Albay, F. (2008). Hentbol, Voleybol Ve Futbol Üniversite Takımlarının Bazı Motorik Ve Antropometrik Özelliklerinin İncelenmesi. Spormetre Beden Eğitimi Ve Spor Bilimleri Dergisi, 6(1), 13-20. https://doi.org/10.1501/Sporm_0000000129

Aslan, C. S., Büyükdere, C., Köklü, Y., Özkan, A., \& Özdemir, F. N. Ş. (2011). Elit altı sporcularda vücut kompozisyonu, anaerobik performans ve sırt kuvveti arasındaki ilişkinin belirlenmesi. Uluslararası InsanBilimleri Dergisi, 8(1), 1612-1628.

Bale, P. (1991). Anthropometric, Body Composition and Performance Variables of Young Elite Female Basketball Players. The Journal of Sports Medicine and Physical Fitness, 31(2), 173.

Bale, P., \& Scholes, S. (1986). Lateral dominance and basketball performance. Journal of Human Movement Studies, $145-151$.

Bozkurt, I., Ozdemır, M., Kadir, P., Ozdemır, O., \& Coskun, A. (2011). Morphometric evaluation of the effect of methenolone enanthate on humeral development in adolescent rat. Scientific Research and Essays, 6(13), 2676-2681.

Bozkurt, I., Pepe, K., Ozdemir, M., Ozdemir, O., \& Coskun, A. (2011). Morphometric evaluation of the effect of methenolone enanthate on femoral development in adolescent rats. Scientific Research and Essays, 6(7), 1634-1638.

Çakmakçı, E., Tatlıcı, A., Kahraman, S., Yılmaz, S., Ünsal, B., \& Özkaymakoğlu, C. (2019). Does once-a-week boxing training improve strength and reaction time? Uluslararast Spor Egzersiz ve Antrenman Bilimi Dergisi, 5(2), 88-92. https://doi.org/10.18826/useeabd.552086

Çakmakçi, E., Tatlici, A., \& Yirmibeş, B. (2018). Comparıson Of Some Performance Parameters of Physıcally Actıve Mentally Retarded and Inactıve Mentally Retarded Individuals. European Journal of Physical Education and Sport Science, 4(12), 49-57.

Carter, J. E., Ackland, T. R., Kerr, D. A., \& Stapff, A. B. (2005). Somatotype and Size of Elite Female Basketball 
Players. Journal of Sports Sciences, 23(10), 1057-1063. https://doi.org/10.1080/02640410400023233

Coleman, A. E., Kreuzer, P., Friedrich, D. W., \& Juvernal, J. P. (1974). Aerobic and anaerobik responses of male colege freshmen during a season of basketball. Journal of Sports Medicine \& Physical Fitness, 14, 26-31,

Csanady, M., Foster, T., \& Högye, M. (1986). Comparative echocarddiographic study of junior and senior basketball players. Int J Sports Med., 7, 128-132. https://doi.org/10.1055/s-2008-1025749

Drinkwater, E. J., Pyne D. B., \& McKenna, M. J. (2008). Design and interpretation of anthropometric and fitness testing of basketball players. Sports Medicine, 38, 565-578. https://doi.org/10.2165/00007256-200838070-00004

Erol, E., \& Sevim, Y. (1993). Çabuk kuvvet çalışmalarının 16-18 yaş grubu basketbolcuların motorsal özellikleri üzerine etkisinin incelenmesi. Hacettepe Üniversitesi Spor Bilimleri Dergisi, 3, 25-37.

Gencer, Y. G., Iğdır, E. C., Temur, H. B., Sarikaya, M., \& Seyhan, S. (2019). El Kavrama Kuvveti Basketbolda Şut İsabetini Etkiler Mi? Electronic Turkish Studies, 14(1). https://doi.org/10.7827/TurkishStudies.13432

Gocentas, A., Landõr, A., \& Andziulis, A. (2004). Dependence of intensity of specific basketball exercise from aerobic capacity. Anthropology, XIII, 9-17.

Güler, U. (2016). 10-16 Yaş Grubu Erkek Basketbol ve Futbolcuların Seçili Antropometrik ve Motorik Özelliklerinin Karşılaş̧tırılması. Master's Thesis, İstanbul Gelişim Üniversitesi Sağlık Bilimleri Enstitüsü, İSTANBUL.

Gür, G., Kılınç, H. E., Ayhan, Ç., \& Tunay, V. B. (2017). Independent Contributions of Upper Extremity Variables in Free Throw Shooting Accuracy from Multiple Positions: A Pilot Study in College Basketball Players. Spor Bilimleri Araştırmaları Dergisi, 2(1), 1-12. https://doi.org/10.25307/jssr.305059

Güvel, H., Kayatekin, M., Özgönül, H., \& Kandemir, F. (1997). Bir basketbol kulübü alt yapı sporcularının fizyolojik ve fiziksel profilleri. Ege Üniversitesi Performans Dergisi, 1-3, 17-22

Hoare, D. G. (2000). Predicting Success in Junior Elite Basketball Players- The Contribution of Anthropometric and Physiological Attributes. Journal of Science and Medicine in Sport, 3(4), 391-405. https://doi.org/10.1016/S1440-2440(00)80006-7

Hoffman, J. R. (2003). Physiology of basketball (Douglas, B. McKeag MD Eds., pp. 12-24). Oxford: Blackwell Science. https://doi.org/10.1002/9780470693896.ch2

Jelicic, M., Sekulic, D., \& Marinovic, M. (2002). Anthropometric Characteristics of High Level European Junior Basketball Players. Collegium Antropologicum (Split), 26, 69-76.

Kalkavan, A., Pınar, S., Kılınç, F., \& Yüksel, O. (2005). Basketbolcu Çocukların Fiziksel Yapılarının, Bazı Fizyolojik ve Biyomotorik Özellikler Üzerine Etkisinin Araştırılması. Sağllk Bilimleri Dergisi, 14(2), 111 119.

Kılınç, F, (2008). An Intensive Combined Training Program Modulates Physical, Physiological, Biomotoric And Technical Parameters in Basketball Player Women. The Journal of Strength and Conditioning Research, 22, 1064-1068. https://doi.org/10.1519/JSC.0b013e3181854bca

Kılınç, F., Erol, A. E., \& Kumartaşlı, M. (2011) Basketbol Alt Yapıda Uygulanan Kombine Teknik Antrenmanların Bazı Fiziksel, Kuvvet ve Teknik Özellikler Üzerine Etkisi. Uluslararası İnsan Bilimleri Dergisi, $8(1)$.

Korkmaz, E. (2013). Farklı Illerdeki Basketbol Takımlarının Bazı Fizyolojik Parametrelerinin Ve Müsabaka Öncesi Sonrası Kan Laktat Seviyelerinin Karşılaştırılması. Doctoral Dissertation, ERZURUM.

Küçük, H., Doğan, E., \& Taşmektepligil, M. Y. (2014). Basketbolcuların Pozisyonlara Göre Performansla İlgili Fiziksel Uygunluklarının Kar\&Scedi; Ila\&Scedi; Tırılması. Kafkas Universitesi. Sosyal Bilimler Enstitu, 13, $65-71$.

Kuter, M., \& Öztürk, F. (1992). Bir erkek basketbol takımının fiziksel ve fizyolojik profili. Hacettepe Üniversitesi İkinci Spor Bilimleri Ulusal Kongresi. HÜ Spor Bilimleri ve Teknolojisi, 221-226.

Kutlay, Ş. (1984). Lise düzeyinde hentbol, voleybol ve basketbolcularla spor yapmayanları bazı fiziksel ve fizyolojik özellikler yönünden karşılaştırllması (pp. 28-33). Ege Üniversitesi Sağlık Bilimleri Enstitüsü Yüksek Lisans Tezi, İzmir.

Magill, A. R. (1989). Motorlearning Concepts and Applications (3rd ed., pp. 17-34). Iowa, Wch, Publishers. 
Menevşe, A. (2013). Basketbolcuların oynadıkları pozisyonlara göre anaerobik güçlerinin karşılaştırılması. Spor ve Performans Araştırmaları Dergisi, 4(1), 33-37.

Özer, Ö., \& Kılınç, F. (2012). Elite athletes in individual and team strength, speed and flexibility to compare their performance. Journal of Human Sciences, 9(1), 360-371.

Pamuk, Ö., Kaplan, T., Taşkın, H., \& Erkmen, N. (2008). Basketbolcularda Bazı Fiziksel ve Fizyolojik Parametrelerin Farklı Liglere Göre İncelenmesi. Spormetre Beden Eğitimi Ve Spor Bilimleri Dergisi, 6(3), 141-144. https://doi.org/10.1501/Sporm_0000000101

Pazarözyurt, İ., \& Gonca, İ. (2009). Elit bayan basketbolcularda antropometrik özellikler, dikey sıçrama ve omurga esnekliğinin mevkilere göre incelenmesi. SPORMETRE Beden Eğitimi ve Spor Bilimleri Dergisi, 7(1), 9-18. https://doi.org/10.1501/Sporm_0000000144

Pepe, K., \& Bozkurt, İ. (2018). A Study on the Weight Losses of Wrestlers and the Impacts of Their Reduced Weight on Their Performance.

Pizzigalli, L., Cremasco, M. M., Torre, A. L., Rainoldi, A., \& Benis, R. (2016). Hand Grip Strength and Anthropometric Characteristics in Italian Female National Basketball Teams. The Journal of Sports Medicine and Physical Fitness, 57(5), 521-528

Polat, S. Ç., \& Çetin, E. (2018). 2. Ligde Oynayan Basketbolcuların Aerobik ve Anaerobik Güçlerinin Bazı Motorik Parametrelerle İlişkilendirilmesi Ve Değerlendirilmesi. Gazi Beden Eğitimi Ve Spor Bilimleri Dergisi, 23(2), 111-118.

Sallet, P., Perrier, D., Ferret, J. M., Vitelli, V., \& Baverel, G. (2005). Physiological Differences in Professional Basketball Players as a Function of Playing Position and Level of Play. The Journal of Sports Medicine and Physical Fitness, 45(3), 291-294.

Scheller, A., \& Rask, B. A. (1993). Protocol for the health and fitness assessment of NBA players. Clin. Sports Med., 12, 193-205.

Taş, M., Sevim, O., Özkan, A., Akyüz, M., Akyüz, Ö., Akyüz, Ö., \& Uslu, S. (2013). Yıldız Basketbol Milli Takımında Yer Alan Kız Sporcuların Anaerobik Performans ve Kuvvet Değerlerinin Belirlenmesinde Çevresel Ölçümlerden Elde Edilen Bazı Değerlerin Rolü. International Journal of Sport Culture and Science, 1(3), 14-23.

Tatlıcı, A., Çakmakçı, E., Yılmaz, S., \& Arslan, F. (2018) Comparison of Visual Reaction Values of Elite Deaf Wrestlers and Elite Normally Hearing Wrestlers. Turkish Journal of Sport and Exercise, 20(2), 63-66. https://doi.org/10.15314/tsed.440813

Tatlici, A., \& Cakmakci, O. (2019). The effects of acute dietary nitrate supplementation on anaerobic power of elite boxers. Medicina Dello Sport, 72(2), 225-233.

Tatlici, A., Sercan, Y., \& Samet, A. (2018). Türkiye'de işitme engelliler ve spor. Türkiye birliği yayınları, 589598.

Temur, H. B. (2017). Alt Ve Üst Ekstremite Çevre Ölçüm Değerleri İle El Kavrama Kuvveti ve Siçrama Mesafesi Arasındaki İlişkinin İncelenmesi. Spor ve Performans Araştırmaları Dergisi, 8(1), 1-9.

Tetik, S., Koç, M., Atar, Ö., \& Koç, H. (2013). Basketbolcularda statik denge performansı ile oyun değer skalası arasındaki ilişkinin incelenmesi. Turkish Kick Boxing Federation Journal of Sport Science, 6(1).

Tsunawake, N., Tahara, Y., Mojı, K., Murakı, S., Minowa, K., \& Yukawa, K. (2003). Body composition and physical fitness of female volleyball and basketball players of the japan inter-high school championship teams. J Physiol Anthropol Appl Human Sci., 22(4), 195-201. https://doi.org/10.2114/jpa.22.195

Ulusu, H. A., Keser, E., \& Gündüz, T. (2018). Basketbol Oyuncularının Antropometrik Özellikleri İle Bazı Performans Değerleri Arasındaki İliş̧kinin İncelenmesi. Mühendislik Bilimleri Ve Tasarım Dergisi, 6, 32-39. https://doi.org/10.21923/jesd.359667

Ünlü, G., \& Tatlıcı, A. (2018). Elit Güreşçilerde Proprioseptif Nöromuskuler Fasilitasyon (Pnf) Uygulamalarının Dinamik Denge Performansına Akut Etkileri. Sportif Bakış: Spor ve Eğitim Bilimleri Dergisi, 57-63

Yıldırım, İ., \& Özdemir, V. (2010). Elit Düzey Erkek Hentbol Oyuncularının Antropometrik Özelliklerinin İncelenmesi. Spor ve Performans Araştırmaları Dergisi, 1(1), 6-13

Yılmaz, A., Müniroğlu, S., Kin İşler, A., ve Akalan, C. (2012). Aerobik ve anaerobik performans özelliklerinin tekrarlı sprint yeteneği ile ilişkisi. Spormetre: Beden Eğitimi ve Spor Bilimleri Dergisi, 20(3), 95-100. 
https://doi.org/10.1501/Sporm_0000000225

Yörükoğlu, U., \& Mitat, K. (2007). Spor Okulu Çalışmaları İle Basketbol Antrenmanlarının 10-13 Yaş Grubu Erkek Çocukların Fiziksel, Fizyolojik Ve Antropometrik Özelliklerine Etkisi. Spormetre Beden Eğitimi ve Spor Bilimleri Dergisi, 5(2), 79-83. https://doi.org/10.1501/Sporm_0000000075

Zorba E. Herkes için spor ve fiziksel uygunluk. Neyir Matbaası. Ankara. 1999.

\section{Copyrights}

Copyright for this article is retained by the author, with first publication rights granted to the journal.

This is an open-access article distributed under the terms and conditions of the Creative Commons Attribution license (http://creativecommons.org/licenses/by/4.0/). 